\title{
PENERAPAN BUSINESS JUDGEMENT RULES DALAM BADAN USAHA MILIK NEGARA STUDI KASUS PT ASURANSI JIWASRAYA
}

\author{
Franky Ariyadi \\ Universitas Muhammadiyah Tangerang, \\ Magister Hukum \\ Jalan Perintis Kemerdekaan I Babakan No.33, RT.007/RW.003, Cikokol, Kec. Tangerang, Kota Tangerang, \\ Banten 15118 \\ *cisadane@yahoo.com
}

\begin{abstract}
In the case of PT Asuransi Jiwasraya, the company's management decision caused the company to suffer a loss. To prove whether the Business Judgement Rulr can be used to protect the decisions that have been made, surely it must proven first: how the decision process is made, both from the legal aspects of the company and the criteria for the Business Judgement Rule.
\end{abstract}

KEYWORDS corporate law, Business Judgement Rule

\section{INTRODUCTION}

Banyak pengurus perusahaan yang memanfaatkan posisinya sebagai nahkoda perusahaan untuk menjalankan perusahaan dengan berbagai macam motivasi.(Aziz \& Shofawati, 2014; Suwati, 2013; Tanujaya, 2015) Namun tentunya tujuan Direksi harus sejalan dengan tujuan stakeholder yang pada umumnya adalah memperoleh keuntungan maksimal dengan kondisi perusahaan tetap dalam keadaan sehat. (Hanifah \& Purwanto, 2013; Lisa, 2012; Nilasari, 2018) Dengan demikian direksi sebagai organ perseroan akan diberi kewenangan tertentu untuk melakukan pengelolaan organisasi dan untuk mencapai hasil optimal dalam mengurus perusahaannya. (Bukhori \& Raharja, 2012; Isfardiyana, 2017; Maulana, 2018) Dalam mengurus perusahaan dikenal dengan Business Judgment Rule untuk melindungi seorang Direksi perusahaan dalam mengambil keputusan agar terhindar dari tindak pidana korupsi.(Butarbutar, 2018; Johnson, 2013; Natasasmita, 2011; Purba, 2011; Wandara, 2017)

Seorang direktur perseroan harus menjalankan usaha perseroan sesuai ketentuan perundang- undangan yang berlaku, termasuk AD/ART. (Akbar, 2016; Lestari, 2015; Widjaja, 2008a, 2008b) Direksi dibebani kewajiban menjalankan tugas sesuai peraturan, fiduciary duty itu mungkin saja beban bagi direksi.(Isfardiyana, 2015; Wardhana, 2019) Tetapi dengan Business Judgment Rule, direksi dapat melaksanakan tugas melalui suatu keputusan bisnis yang diambil dengan penuh tanggung jawab tanpa ada rasa takut bahwa 
ia akan dibebani tanggung jawab personal jika keputusan yang diambil merugikan perseoran.(Affandhi et al., 2015; Hatta, 2010; Kusumawardani, 2013; Rajagukguk, 2014)

Masalah mulai muncul ketika banyak perusahaan sejenis yang bersaing satu sama lain. Pada titik inilah Direksi dituntut tetap berkreativitas, inovasi menemukan strategi mencapai tujuannya. (Priyanto, 2010) Sumber pendapatan perusahaan adalah melalui bisnis utamanya, namun demikian masih ada sumber pendapatan lainnya yaitu investasi. (Erosvitha \& Wirawati, 2016; Fenandar \& Raharja, 2012; Pardiansyah, 2017)

Dalam melakukan investasi, beberapa hal yang harus dipastikan bahwa dalam mengambil keputusan pada suatu perusahaan adanya istilah high risk, high return". Semakin tinggi risiko yang diambil dalam suatu investasi, maka semakin tinggi pula keuntungan yang mungkin akan didapatkan perusahaan tersebut. (Dita \& Akhmad, 2018; Nilasari, 2018; Wulandari \& Iramani, 2014) Investasi merupakan suatu kegiatan menempatkan dana pada satu atau lebih dari satu aset selama periode tertentu, dengan harapan dapat memperoleh penghasilan dan atau peningkatan investasi. (Harianto \& Sudomo, 2011)

Secara definisi pengertian investasi adalah Investment is any vehicle into which funds can be played with expectation that it will generate positive income and/or preserve or increase its value. Adapun terjemahan bebas dari definisi adalah suatu sarana dimana dana dapat ditempatkan dengan harapan hal tersebut akan menghasilkan pendapatan.(Hidayat, 2014; Tandelilin, 2012) Sebagai contoh Kasus Asuransi PT Jiwasraya. Kasus PT Asuransi Jiwasraya merupakan salah satu kasus yang sangat menarik, baik dalam jumlah kerugian yang ditanggung, modus operandi dan bagaimana cara pengelolaannya. Namun demikian, tulisan ini hanya membahas aspek hukum terkait kasus dimaksud.

Kasus ini berawal dari PT Asuransi Jiwasraya yang tengah mengalami kesulitan kinerja, kemudian menjual produknya JS Saving Plan dengan cost of fund yang sangat tinggi di atas bunga deposito dan obligasi. Akhirnya memaksa PT Asuransi Jiwaraya, mencari investasi high return. Oleh Jiwasraya, dana nasabah diinvestasikan pada instrument saham dan reksadana. Saham-saham yang beresiko inilah yang mengakibatkan negative spread pada dan menimbulkan tekanan likuiditas PT Asuransi Jiwasraya yang berujung pada gagal bayar.

Jaksa Agung Burhanuddin menyatakan PT Asuransi Jiwasraya (Persero) melakukan pelanggaran prinsip kehati-hatian dalam berinvestasi sehingga mengakibatkan kerugian negara Rp 13,7 triliun. Akibat kesalahan investasi, penuntasan hukum akan menjadi langkah bijak dan menarik dikaji guna menempatkan sifat kesalahan sesuai proporsi hukumnya. (J. Gitman, 2005; L. J. Gitman et al., 2015) Dugaan korupsi kasus Jiwasraya dalam pengelolaan dana investasi menjadi bagian penting yang dapat ditelisik dan ditelusuri kebenaran hukumnya. Pemeriksaan kepada jajaran direksi guna menemukan titik terang hukumnya, menjadi persoalan publik bagaimana menilai suatu nilai kerugian dalam hukum.

Permasalahan yang akan penulis bahas pada artikel ini adalah bagaimana penerapan Business Judgement Rule dalam Perseroan (BUMN) dan apakah tindakan pengurus PT Asuransi Jiwasraya dapat dikategorikan sebagai Business Judgement Rule. 


\section{METHODOLOGY}

Metologi penelitian ini adalah penelitian hukum normatif yaitu penelitian yang didasarkan pada penelitian kepustakaan dengan menggunakan pendekatan terhadap masalah-masalah yang diteliti, dengan cara meninjau dari segi peraturan perundangundangan yang berlaku dan bahan hukum lainnya. Sebagai penelitian hukum normatif, metode pendekatan yang dipergunakan dalam penelitian ini adalah pendekatan perundang-undangan (statute approach) dan pendekatan konseptual (conceptual approach).

Bahan hukum yang dipergunakan dalam penelitian ini adalah hukum primer yang terdiri dari peraturan perundang-undangan, yaitu meliputi Undang-Undang Nomor 40 Tahun 2007 tentang Perseroan Terbatas dan putusan-putusan pengadilan yang telah berkekuatan hukum tetap. Data sekunder yaitu data yang sudah tersedia ditempat penelitian yang diperoleh melalui penelitian kepustakaan (library research) dengan mempelajari buku-buku literatur, peraturan perundang-undangan, jurnal ilmiah dan lainlain yang berhubungan dengan obyek penelitian.

\section{RESULTS AND DISCUSSION}

Pada hakekatnya Business Judgement Rule merupakan suatu doktrin yang mengajarkan bahwa putusan direksi dalam suatu aktivitas perseroan tidak dapat diganggu gugat siapa pun, meskipun putusan itu akhirnya membawa kerugian bagi perseroan.(Akbar, 2016) Dasar pemikiran doktrin ini bertolak dari karakteristik bisnis yang sulit untuk diprediksi (unpredictable) dan tidak dapat ditentukan secara pasti akibat dan hasilnya, karena sangat tergantung dari berbagai faktor yang mempengaruhinya. (Mulyana, 2018)

Undang-Undang No 40 tahun 2014 tentang Perasuransian secara tegas menyatakan bahwa perusahaan asuransi wajib menerapkan tata kelola perusahaan yang baik, yang tentunya dijalankan dengan itikad baik (good faith). Apabila pasal 11 ayat (1) ini tidak dijalankan, maka pertanggungjawaban hukum harus ditegakkan atau dijalankan. Di Pasal 11 ayat (1) ini menegaskan bahwa pengelolaan suatu perusahaaN asuransi harus dilakukan berdasarkan itikad yang baik. Setiap adanya penyalahgunaan atas pengelolaan perusahaan yang dijalankan dengan tidak baik, merupakan suatu bentuk pelanggaran hukum dan oleh sebab itu akan dikenakan sanksi hukum. Itikad baik (good faith) merupakan salah satu karakeristik apakah Business Judgement Rule dapat terpenuhi atau tidak. Karakteristik lainnya antara lain: pengambilan keputusan telah memperhatikan kepentingan perusahaan (fiduciary duty), berdasarkan pengetahuan/data yang memadai (informed basis), tidak dilakukan untuk berhambur-hambur (duty of care) dan tidak didasarkan pada kepentingan pribadi (loyalty). Apabila perusahaan berbentuk perseroan, maka wajib tunduk pada Undang-Undang Perusahaan Terbatas.

Justifikasi parameter legal mengenai Business Judgement Rule dapat dilihat pada Pasal 97 ayat (5) yang mengatakan bahwa anggota Direksi tidak dapat dipertanggungjawabkan atas kerugian sebagaimana dimaksud pada ayat (3) apabila dapat membuktikan:

1. Kerugian tersebut bukan karena kesalahan atau kelalaiannya;

2. Telah melakukan pengurusan dengan itikas baik (good faith) dan kehati-hatian untuk kepentingan dan sesuai dengan maksud dan tujuan Perseroan; 
3. Tidak mempunyai benturan kepentingan, baik langsung maupun tidak langsung atas tindakan pengurusan yang mengakibatkan kerugian (loyalty); dan

4. Telah mengambil tindakan untuk mencegah timbul atau berlanjutnya kerugian tersebut. (Juwana, 2019)

Sedangkan untuk Dewan Komisaris diberlakukan Pasal 114 ayat (5) yang menjelaskan bahwa anggota Dewan Komisaris tidak dapat dipertanggungjawabkan atas kerugian sebagaimana dimaksud pada ayat (3) apabila dapat membuktikan:

a. Telah melakukan pengawasan dengan itikad baik dan kehati-hatian untuk kepentingan Perseroan dan sesuai dengan maksud dan tujuan Perseroan;

b. Tidak mempuyai kepentingan pribadi, baik langsung maupun tidak langsung atas tindakan pengurusan Direksi yang mengakibatkan kerugian ; dan

c. Telah memberikan nasihat kepada Direksi untuk mencegah timbul atau berlanjutnya kerugian tersebut

Sedangkan khusus untuk Perusahaan Terbuka (Tbk), maka Otoritas Jasa Keuangan (OJK) juga mengadopsi doktrin Business Judgement Rule dengan kebijakan OJK, yang menjelaskan bahwa :

1) Kerugian tersebut bukan karena kesalahan atau kelalaiannya;

2) Telah melakukan pengurusan dengan itikad baik, penuh tanggung jawab, dan kehati-hatian untuk kepentingan dan sesuai dengan maksud dan tujuan emiten atau perusahaan publik;

3) Tidak mempunyai benturan kepentingan baik langsung maupun tidak langsung atas tindakan pengurusan yang mengakibatkan kerugian, dan

4) Telah mengambil tindakan untuk mencegah timbul atau berlanjutnya kerugian tersebut.

Dari penjelasan di atas, maka Direksi memiliki wewenang yang sangat besar dalam menjalankan perseroan yang dipimpinnya, sehingga selama tindakan Direksi tersebut dilakukan demi kepentingan perusahaan, maka tindakan yang telah dilakukannya dapat dibenarkan.

Direksi yang masih ragu-ragu atau bahkan tidak berani mengambil risiko, sehingga menghambat perkembangan Perseroan. Dan mengingat pada umumnya tujuan perseroan adalah ingin maju dan berkembang, maka tindakan yang tidak berani ambil risiko dianggap sebagai suatu putusan, sehingga sangat kecil peluang stakeholder mempertahankan kepengurusan seperti ini.

Dengan adanya Business Judgement Rule, dapat dijadikan Direksi sebagai pedoman untuk menjalankan Perseroan tanpa ada keraguan. Badan Usaha Milik Negara atau BUMN merupakan badan usaha yang seluruh atau sebagian besar modalnya dimiliki oleh negara melalui penyertaan secara langsung yang berasal dari kekayaan negara yang dipisahkan. PT Asuransi Jiwasraya merupakan BUMN yang bentuknya perseroan terbatas, yang tujuan utamanya mengejar keuntungan.

Pemilihan Pengurus Perseroan yang dilakukan melalui Rapat Umum Pemegang Saham (RUPS), merupakan awal dari legalitas dan wewenang seseorang untuk menjadi pengurus Perseroan. Namun demikian, hal ini belumlah cukup bagi pengurus yang terpilih untuk menjalankan Perseroan karena masih ada keraguan terhadap yang akan risiko yang dihadapinya, khususnya dalam mengelola dan memutuskan suatu kebijakan terkait 
Perseroan. Pengurusan BUMN dilakukan oleh Direksi, dan Direksi bertanggung jawab penuh atas pengurusan BUMN untuk kepentingan dan tujuan BUMN, baik di dalam maupun di luar pengadilan

Penulis berpendapat bahwa dengan telah diakomodirnya Business Judgement Rule dalam Undang-Undang, maka sudah seharusnya pengurus Perseroan tidak ragu-ragu dalam melakukan pengelolaan Perseroan.

Untuk memastikan bahwa pengelolaan Perseroan telah dijalankan dengan benar, dapat dilihat dari upaya Pengurus dalam melakukan pengelolaan Perseroan. Sebagai contoh, apabila Perseroan ingin memberikan putusan terkait usaha Perseroan, maka sudah beberapa upaya yang seharusnya dilakukan antara lain: menghimpun dan mempertimbangkan pengetahuan atau data atau informasi atau kajian yang memadai dari unit bisnis, legal, keuangan atau unit lainnya.

Dari hasil informasi, pengetahuan dan kajian ini, maka putusan yang dihasilkan menjadi landasan bahwa pengurus telah menjalankan Perseroan dengan penuh kehatihatian, memiliki itikad baik, dan berlandaskan due of care dan informed basis dalam menandatangi suatu kebijakan serta hal lainna sebagaimana yang tertulis dalam UUPT.

Untuk menguji dipenuhi atau tidaknya prinsip- prinsip Business Judegment Rule yang dilakukan oleh pengurus Perseroan, maka dilakukan dalam bentuk pertanggungjawaban Direksi di hadapan Rapat Umum Pemegang Saham (RUPS). Bila pertanggungjawaban diterima, maka manajemen dibebaskan dari tanggungjawab Perseroan, termasuk bila ada kerugian yang diderita oleh Perseroan.

Bila pertanggungjawaban tidak diterima, pemegang saham atas nama perusahaan yang mewakili sedikitnya 1/10 (satu persepuluh) bagian dari jumlah seluruh saham dengan hak suara dapat mengajukan gugatan melalui Pengadilan Negeri terhadap anggota direksi yang karena kesalahan atau kelalaiannya menimbulkan kerugian pada perseroan.

Apabila pemegang saham mayoritas menerima pertanggungjawaban pengurus, namun pemegang saham minoritas berpendapat lain, maka pemegang saham minoritas juga dapat membawa gugatan pertanggungjawaban kerugian itu ke hadapan pengadilan. Pemegang Saham yang menggugat harus membuktikan: apakah manajemen melaksanakan atau tidak Business Judegement Rule dalam pengambilan keputusannya.

Dalam mengambil suatu kebijakan, maka pengurus Perseroan perlu meminta kajian secara internal apakah ada risiko-risiko yang mungkin bisa timbul: dari risiko paling tinggi (high risk) sampai paling rendah (low risk), aspek-aspek lainnya seperti legal, kepatuhan, dan lain sebagainya. Misalnya, berdasarkan hasil pengkajian internal tersebut, apabila pengurus Perseroan tidak mengambil keputusan atas kebijakan itu, perseroan bisa terancam pailit, atau risiko yang yang akan dihadapinya lebih besar, dan lain sebagainya maka hal inilah yang menjadi dasar keputusan untuk memutuskan suatu kebijakan. Keputusan seperti ini termasuk termasuk salah satu alasan pembenar atas kebijakan pengurus Perseroan.

Setelah keputusan tersebut diambil, hal penting lainnya adalah pengarsipan atas keputusan yang dibuat dan kajian-kajian internal yang menjadi dasar pengambil keputusan, termasuk Standar Operasional Prosedur (SOP) Perseroan dalam pengambilan kebijakan. 
Dalam praktiknya, pengarsipan atas hasil kajian dan SOP dimaksud seringkali disepelekan, sehingga terkadang sulit dicari atau bahkan tidak pernah ditemukan (hilang). Apabila pengarsipan dilakukan secara tertib dan teratur, maka akan terlihat apakah keputusan yang diambil Perseroan tersebut sudah benar ataukah sebaliknya. Hal penting lainnya adalah penerapan Pedoman Standar Akuntansi Keuangan (PSAK) yang dipergunakan dalam melakukan kalkulasi atas kerugian atau keuntungan suatu usahanya.

Masih ada beberapa Perseroan yang melakukan kekeliruan dalam memakai PSAK sebagai pedoman akuntasi Perseroannya, sehingga kerugian atau keuntungan yang diperoleh menjadi tidak akurat (overvalued atau undervalued). Kasus PT Asuransi Jiwasraya: Dibenarkan secara Business Judgement Rule atau Tidak? Salah satu kasus besar di Tanah Air pada beberapa bulan lalu sampai dengan saat ini adalah kasus yang menimpa PT Asuransi Jiwasraya.

Secara singkat, PT Asuransi Jiwasraya tidak dapat mengembalikan dana nasabah yang jumlahnya sementara Rp 13,7 triliun. Dampak lebih jauh adalah muncullnya dugaan korupsi dalam kasus Jiwasraya, khususnya dalam pengelolaan dana investasi. Terlebih jika pengurus Perseroan melanggar Undang-Undang Korupsi, maka sudah sepatutnya dikenakan hukuman karena sudah merugikan banyak pihak dan merusak ekonomi bangsa.

Pengelolaan investasi yang dilakukan oleh pengurus Jiwasraya menjadi sangat penting, mengingat sebagian besar hasil investasi yang dilakukan oleh Jiwasraya menjadi bermasalah, yang menyebabkan Jiwasraya tidak dapat membayarkan premi ke para nasabahnya yang sudha jatuh tempo. Pertanyaan yang timbul adalah apakah pengurus Jiwasraya sudah melakukan tindakan-tindakan internal yang memadai dan penuh kehatihatian, sehingga dapat dikategorikan sebagai Business Judgement Rule ataukah sebaliknya.

Pengurus Perseroan yang dibantu oleh unit risk, unit bisnis, unit-unit lainnya seperti legal, kepatuhan haruslah berpegang pada norma UUPT, dengan maksud agar semua hal terkait Perseroan, untuk kepentingan Perseroan, dilakukan sesuai dengan maksud dan tujuan Perseroan, dan dilakukan secara benar. Dewan Komisaris yang dalam melakukan tugasnya, memiliki wewenang melakukan pengawasan terhadap pengelolaan Perseroan dibantu oleh Komite Audit dan juga Komite Risiko, sehingga ikut bertanggung jawab atas kebijakan pengurusan, memberikan nasihat kepada Direksi dan memastikan semua mekanisme berjalan efektif sesuai aturan-aturan yang ada.

Aktifitas Dewan Komisaris lainnya adalah membuat penilaian atas kerugian pada saat usaha (bisnis) Perseroan sedang berjalan, dalam arti Komisaris benar-benar memastikan bahwa kebijakan yang diambil Direksi sudah melalui kajian internal yang memadai. Adanya kerugian atau keuntungan menjadi sisi yang melekat dan menyatu dalam usaha.

Dari penjelasan di atas, maka tindakan pengurus Perseroan Jiwasraya dalam melakukan pengelolaan Perseroan, khususnya terkait investasi yang akhirnya menjadi salah satu penyebab Jiwasyara tidak bisa mengembalikan dana nasabahnya, dapat dikategorikan sebagai Business Judgement Rule apabila pengurus Perseroan mampu membuktikan bahwa Perseroan dikelola secara professional dan di dalam batas-batasan peraturan (internal dan eksternal) yang berlaku. Hal terakhir, namun penting adalah adanya arsip (dokumentasi) dari semua kebijakan yang diambil, sehingga kronologis dari munculnya kebijakan tersebut dapat dilihat dan dinilai semua pihak. Selain itu juga perlu 
dilihat apakah akuntasi yang dipergunakan Jiwasraya sudah sesuai dengan pedoman akuntasi yang ada.

Hal ini untuk memastikan bahwa hasil usaha yang dilakukan pengurus Perseroan sudah dinilai atau dihitung berdasarkan dengan benar, sehingga hasilnya dapat dipertanggungjawabkan. Dengan menilai analisis awal atas persoalan hukum Jiwasraya, kiranya publik bisa memahami bahwa persoalan kerugian suatu usaha tidak harus selalu dipahami dalam konteks hukum, melainkan juga harus dipahami juga dalam konteks akuntansi, agar keadilan dan kepastian hukum dapat dipahami bersama secara proporsional sekaligus sebagai pembelajaran bagi semua pihak.

Kesimpulan Dalam menjalankan Perseroan, sudah sepatutnya pengurus Perseroan tidak mengejar keuntungan yang cepat dalam waktu singkat. Konsep bisnis seperti "Semakin tinggi risiko yang diambil dalam suatu bisnis, semakin tinggi pula keuntungan yang mungkin akan didapatkan suatu Perseroan" (High Risk, High Return) menjadikan pengurus untuk selalu berhati- hati dalam menjalankan Perseroan.

Kesalahan dalam melakukan pengelolaan Perseroan, tanpa memperhitungkan faktor risiko yang dihadapi, sehingga menjaidkan perusahaan merugi akan memberikan peluang kemungkinan pengurus Perseroan beserta jajarannya diminta pertanggungjawaban atas keputusan-keputusan yang telah diambilnya tersebut, baik secara perdata maupun pidana. Namun demikian, bukan berarti pengurus Perseroan dapat bersikap pasif atas pengelolaan Perseroan karena menghindari risiko yang ada. Bersikap pasif pun merupakan suatu keputusan, dan apabila keputusan ini menyebabkan banyak peluang (keuntungan) Perseroan yang hilang atau tidak bisa diperoleh, tentunya stakeholder akan mengambil sikap atas keputusan ini. Apabila selama ini pengurus dihadapkan keraguan, bahkan ketakutan dalam mengelola Perseroan, maka dengan adanya Business Judgement Rule ini akan membuat keraguan atau ketakutan tersebut berkurang atau bahkan menghilang.

Hal ini disebabkan karena pada hakekatnya Business Judgement Rule merupakan "payung hukum" bagi para pengurus Perseroan dalam menjalankan pengelolaan Perseroan. Selama pengurus mengelola Perseroan dilakukan secara professional, dalam batas-batas kehati-hatian, adanya kajian sebelum pengambilan keputusan, senantiasa berpedoman pada rambu-rambu aturan yang berlaku seperti Standar Operating Procedures (SOP) ataupun kebijakan-kebijakan lainnya, termasuk juga sistem dokumentasi yang lengkap, maka tidak ada lagi yang perlu dikhawatirkan.

Dalam kasus PT Asuransi Jiwasraya, maka keputusan pengurus Perseroan dalam melakukan pengelolaan juga harus dicermati dengan baik, antara lain: apakah keputusan untuk melakukan investasi di produk-produk investasi seperti saham-saham, atau produk investasi lainnya telah melalui mekanisme internal yang ada, seperti adanya itikad baik (good faith), melalui SOP yang berlaku, adanya kajian internal dari unit risiko (risk unit), unit kepatuhan (compliance unit), unit bisnis (business unit), unit hukum (legal unit) dan unit-unit terkait lainnya, termasuk keputusan untuk menerbitkan produk investasi yang memiliki return yang tinggi: apakah sudah melalui mekanisme seperti halnya investasi di saham? Dalam Business Judgement Rule, kelengkapan dan arsip atau dokumentasi mempunyai peranan yang penting. Karena dokumentasi merupakan bukti pendukung atas 
keputusan yang telah diambil oleh pengurus Perseroan: apakah dibuat berdasarkan mekanisme peraturan yang sudah ada atau melalui mekanisme lainnya (illegal).

\section{CONCLUSION}

Adagium high risk, high return atau semakin tinggi risiko yang diambil dalam suatu bisnis, maka semakin tinggi juga potensi keuntungan yang akan diperoleh suatu perusahaan. Namun demikian, pengambilan keputusan yang berisiko tinggi atau ketidaktelitian dalam mengkalkulasi risiko yang akan ditanggung, yang mengakibatkan perusahaan mengalami kerugian akan memiliki dampak pemeriksaan terhadap jajaran manajemen (direksi dan komisaris) dan jajarannya untuk dimintakan pertanggungjawaban terhadap keputusan yang berisiko tersebut, baik dalam bentuk gugatan pertanggungjawaban secara perdata bahkan tuntutan pidana.

Bahkan dalam Pasal 97 ayat (3) UU PT disebutkan bahwa anggota Direksi bertanggungjawab secara pribadi atas kerugian perseroan bilamana bersalah atau lalai menjalankan tugas pengurusan dengan itikad baik (good faith) dan penuh tanggungjawab. Dalam Pasal 155 UU PT, pertanggungjawaban Direksi atau Komisaris atas kesalahan dan kelalaiannya tidak mengurangi pertanggungjawaban di bidang pidana.

Dalam kasus PT Asuransi Jiwasraya pun demikian. Keputusan yang telah diambil manajemen (direksi atau komisaris) seharusnya sudah melalui tahapan-tahapan sebagaimana disebutkan di atas, khususnya adanya kajian risiko, bisnis dan yang terpenting adalah kepatuhan atas standard operating procedures (SOP) yang berlaku. Dengan melihat ini semua, maka para pemegang saham dapat dengan cepat menilai: apakah keputusan yang diambil tersebut masuk dalam kategori Business Judgement Rule ataukah tidak.

Setiap keputusan yang diambil oleh direksi dan komisaris memiliki catatan tersendiri bagi para pemegang saham mayoritas: apakah manajemen yang ada akan tetap dipertahankan atau harus diganti. Justifikasi parameter legal mengenai Business Judgement Rule dapat dilihat pada Undang-Undang Perseroan Terbatas (UU PT) yang mengatur batasan-batasan tertentu mengenai kapan direksi dan komisaris tidak dapat dimintakan pertanggungjawaban atas risiko $\mathrm{k}$

Adanya godaan untuk memperoleh keuntungan sebanyak-banyaknya merupakan hal yang umum dirasakan oleh setiap direksi dan komisaris di suatu perusahaan. Namun demikian, hendaknya juga perlu diingat bahwa dalam menjalankan perseroan, direksi dan komisaris memiliki batasan-batasan sesuai dengan perundang-undangan dan peraturan lainnya yang berlaku. Dan semua peraturan dan perundang-undangan ini tentunya tidak sekedar diingat, namun yang lebih penting juga harus dipatuhi.

\section{REFERENCES}

Affandhi, F., Nasution, B., Siregar, M., \& Mulyadi, M. (2015). Business Judgement Rule Dikaitkan dengan Tindak Pidana Korupsi yang Dilakukan oleh Direksi Badan USAha Milik Negara terhadap Keputusan Bisnis yang Diambil. USU Law Journal, 4(1), 33-44. Akbar, M. G. G. (2016). Business Judgement Rule Sebagai Perlindungan Hukum Bagi Direksi Perseroan dalam melakukan Transaksi Bisnis. Justisi Jurnal Ilmu Hukum, 1(1). 
Aziz, R., \& Shofawati, A. (2014). Pengaruh Kepemimpinan islami dan Budaya organisasi islami Terhadap Motivasi kerja Islami pada UMKM Kulit di Magetan. Jurnal Ekonomi Syariah Teori Dan Terapan, 1(6).

Bukhori, I., \& Raharja, R. (2012). Pengaruh good corporate governance dan ukuran perusahaan terhadap kinerja perusahaan (studi empiris pada perusahaan yang terdaftar di BEI 2010) [PhD Thesis]. Fakultas Ekonomika dan Bisnis.

Butarbutar, R. (2018). Pertanggungjawaban Korporasi Dalam Tindak Pidana Korupsi Pengadaan Barang Dan Jasa Pemerintah Di Bidang Konstruksi. Jurnal Penelitian Hukum Legalitas, 9(1), 51-66.

Dita, K., \& Akhmad, R. (2018). Pengaruh Keputusan Investasi, Keputusan Pendanaan dan Kebijakan Dividen Terhadap Nilai Perusahaan. Jurnal Ilmu Dan Riset Akuntansi (JIRA), $7(1)$.

Erosvitha, C. K. L., \& Wirawati, N. G. P. (2016). Pengaruh Profitabilitas, Set Kesempatan Investasi, Pertumbuhan Penjualan Dan Risiko Bisnis Pada Struktur Modal. E-Jurnal Akuntansi, 172-197.

Fenandar, G. I., \& Raharja, S. (2012). Pengaruh keputusan investasi, keputusan pendanaan, dan kebijakan dividen terhadap nilai perusahaan [PhD Thesis]. Fakultas Ekonomika dan Bisnis.

Gitman, J. (2005). Principle of Managerial Finance 11th edition. United State. Pearson Education, Inc.

Gitman, L. J., Juchau, R., \& Flanagan, J. (2015). Principles of managerial finance. Pearson Higher Education AU.

Hanifah, O. E., \& Purwanto, A. (2013). Pengaruh Struktur Corporate Governance dan Financial Indicators terhadap kondisi financial Distress (Studi pada perusahaan manufaktur yang terdaftar di Bursa Efek Indonesia Periode 2009-2011) [PhD Thesis]. Fakultas Ekonomika dan Bisnis.

Harianto, F., \& Sudomo, S. (2011). Perangkat dan Teknik Analisis Investasi di Pasar Modal Indonesia. PT. Bursa Efek Jakarta, Jakarta.

Hatta, C. (2010). Tinjauan Yuridis Tanggung Jawab Direktur PT. Terhadap Kepailitan PT. Dikaitkan Dengan Prinsip Business Judgment Rule.

Hidayat, R. W. (2014). Peluang dan Tantangan Investasi Properti di Indonesia. Jurnal Akuntansi AKUNESA, 2(2).

Isfardiyana, S. H. (2015). Tanggung Jawab Direksi Perseroan Terbatas dalam Pelanggaran Fiduciary Duty. Padjadjaran Journal of Law, 2(1). 
Isfardiyana, S. H. (2017). Business Judgement Rule Oleh Direksi Perseroan. Jurnal Panorama Hukum, 2(1), 1-20.

Johnson, L. (2013). Unsettledness Delaware Corporate Law: Business Judgment Rule, Corporate Purpose. Del. J. Corp. L., 38, 405.

Juwana, H. (2019). Business Judgement Rule: Penerapan Perlindungan Hukum terhadap Organ Perusahaan dalam Aktivitas Bisnis Perusahaan Makalah Workshop HukumOnline.

Kusumawardani, S. I. (2013). Pengaturan Kewenangan, dan Tanggung Jawab Direksi dalam Perseroan Terbatas (Studi Perbandingan Indonesia dan Australia). Jurnal Magister Hukum Udayana (Udayana Master Law Journal), 2(1).

Lestari, S. N. (2015). Business Judgment Rule Sebagai Immunity Doctrine Bagi Direksi Badan Usaha Milik Negara di Indonesia. NOTARIUS, 8(2), 302-314.

Lisa, O. (2012). Asimetri Informasi dan manajemen laba: Suatu tinjauan dalam hubungan keagenan. Wiga: Jurnal Penelitian Ilmu Ekonomi, 2(1), 36615.

Maulana, R. S. (2018). Kedudukan Direktur Sebagai Pekerja Menurut Undang-Undang Ketenagakerjaan [PhD Thesis]. UNIVERSITAS 17 AGUSTUS 1945.

Mulyana, A. (2018). Business Judgement Rule Versus Tindak Pidana Korupsi. Media Indonesia.

Natasasmita, B. I. (2011). Diskresi sebagai Tindak Pidana Korupsi: Kajian Kriminologi dan Hukum terhadap Fenomena Pejabat Otoritas. MIMBAR: Jurnal Sosial Dan Pembangunan, 27(2), 143-149.

Nilasari, A. (2018). Pengaruh Intensitas Persediaan, Intensitas Aset Tetap, Likuiditas, Leverage, Dan Ukuran Perusahaan Terhadap Tingkat Agresivitas Wajib Pajak Badan Pada Perusahaan Manufaktur Sub Sektor Otomotif Yang Terdaftar Di Bei Periode 20132017 [PhD Thesis]. Universitas Islam Negeri Sultan Syarif Kasim Riau.

Pardiansyah, E. (2017). Investasi dalam Perspektif Ekonomi Islam: Pendekatan Teoritis dan Empiris. Economica: Jurnal Ekonomi Islam, 8(2), 337-373.

Priyanto, I. F. (2010). Kepemimpinan, Inovasi dan Kreativitas Pustakawan Indonesia.

Purba, O. (2011). Petunjuk Praktis bagi RUPS, Komisaris, dan Direksi Perseroan Terbatas agar Terhindar dari Jerat Hukum. RAIH ASA SUKSES.

Rajagukguk, E. (2014). Perlindungan Hukum Terhadap Risiko Pengambilan Keputusan Yang Diambil Oleh Direktur dan Komisaris. Disampaikan Pada Panel Diskusi “Governance Dan Risiko Kriminalisasi: Kasus Di Industri Telekomunikasi" Yang Diselenggarakan Oleh Lembaga Komisaris Dan Direktur Indonesia (LKDI), Di Jakarta, 30.

Suwati, Y. (2013). Pengaruh kompensasi dan motivasi kerja terhadap kinerja karyawan pada PT. Tunas Hijau Samarinda. Jurnal Ilmu Administrasi Bisnis, 1(1), 41-55. 
Tandelilin, E. (2012). Manajemen Investasi.

Tanujaya, L. R. (2015). Pengaruh Pelatihan Kerja dan Motivasi Kerja pada Kinerja Karyawan Departemen Produksi PT Coronet Crown. Agora, 3(1), 1-7.

Wandara, M. A. R. (2017). Penerapan Prinsip Business Judgement Rule Terhadap Pertanggungjawaban Pidana Direksi Dalam Tindak Pidana Korupsi [PhD Thesis]. Fakultas Hukum Universitas Pasundan.

Wardhana, G. P. (2019). BUSINESS JUDGEMENT RULE SEBAGAI PERLINDUNGAN ATAS PERTANGGUNGJAWABAN PRIBADI DIREKSI PERSEROAN. Jurnal Riset Manajemen Dan Bisnis, 14(1), 59-60.

Widjaja, G. (2008a). 150 pertanyaan tentang perseroan terbatas: Membahas secara lengkap \& tuntas berdasarkan UU no. 40 th. 2007 \& peraturan pelaksanaannya tentang pendirian, $A D / A R T$ PT, modal \& saham PT, RUPS, peran direksi \& komisaris, corporate social responsibility (CSR), penggabungan, peleburan, pengambilalihan, pemisahan PT, pemeriksaan, pembubaran \& likuidasi PT. Niaga Swadaya.

Widjaja, G. (2008b). Risiko hukum pemilik, direksi \& komisaris PT: Piercing the corporate veil: memberlakukan tanggung jawab pribadi pemegang saham, direksi \& dewan komisaris menurut UU PT no. 40 thn 2007. Niaga Swadaya.

Wulandari, D. A., \& Iramani, R. (2014). Studi Experienced Regret, Risk Tolerance, Overconfidance Dan Risk Perception Pada Pengambilan Keputusan Investasi. Journal of Business and Banking, 4(1), 55-66. 